\title{
Immigration and Structural Change: The Canadian Experience, 1971-19861
}

Anthony H. Richmond

The educational, occupational, industrial and income characteristics of immigrants in Canada, 1971-1986, are considered in the context of postindustrial structural changes in the economic and social system, including declining primary and secondary sectors. Seven alternative theoretical models are reviewed. A composite model of "segmented structural change" is found to correspond more closely than alternative theoretical perspectives to the empirical evidence. Specifically, immigrants are found at all levels of the system, but there is differential incorporation by gender, ethnicity and period of immigration. Recent immigrants from Third World countries tend to be disadvantaged.

The economic and social systems of advanced industrial societies have undergone major structural changes in the last twenty years. These changes have a significant impact on the process of immigrant absorption. Among the most important effects are the growth of metropolitan areas, the improved level of education of the populations of sending and receiving societies, together with the transition from industrialism to postindustrialism. The latter is evident in the declining importance of the primary and secondary sectors of industry and the growth of the tertiary sectors. These include technologically advanced fields such as banking, finance and information processing associated with computerization, as well as traditional service industries such as domestic employment, catering, etc. These economic and social changes have occurred simultaneously with demographic shifts from "baby boom" to "baby bust," with a consequent aging population

\footnotetext{
1 This is a revised version of a paper presented at the conference, "Social and Economic Dimensions of Immigration and Multiculturalism" at the Institute of Applied Economic and Social Research, University of Melbourne, Australia, July 28, 1989. I am indebted to Shirley Seward, The Institute of Research on Public Policy, Ottawa, for helpful comments on an earlier draft and permission to use special tabulations from the 1986 Census of Canada. An anonymous referee also made valuable suggestions for revision.
} 
and a substantial increase in female labor force participation. In the case of Canada, the structural changes also have been accompanied by deliberate attempts to recruit well-qualified immigrants and a "business class" of entrepreneurs with capital to invest. At the same time, there has been an emphasis on family reunion and some refugee migration.

A substantial shift from traditional to nontraditional source countries has taken place. ${ }^{2}$ In the postwar period, up to 1961 , immigrants from Britain were the largest single source; those surviving constituted almost 22 percent of that cohort in 1986. However, those of British origin were only 7.5 percent of those who arrived in the mid-1980s. In 1988, they were less than 5 percent of the total intake. Other traditional source countries in Europe now supply only 20 percent of the total arrivals. Since 1962, the Asian populations have been the fastest growing. Almost three quarters of Canada's annual immigration presently comes from Third World countries, with Asian, Caribbean and Latin American countries predominating. The composition of the Canadian population in 1986, by ethnic origin and period of immigration, is shown in Table 1.

Immigrants are not evenly distributed throughout the country. Postwar immigrants, as well as more recent arrivals, have gravitated to Canada's metropolitan centers which are growing economically, while Canada's older established populations (the Canadian-born of Canadian parentage of largely British and French origin) are disproportionately represented in the rural and maritime hinterlands, where economic opportunities are limited. ${ }^{3}$ In $1986,15.6$ percent of the total population was foreign born, but the average for 25 Census Metropolitan areas was 21.2 percent. The proportion for Toronto was 36.3 percent, about a quarter of whom arrived in the decade 1976-86. The black and Asian populations were even more highly concentrated in Montreal, Toronto and Vancouver.

Among the changes which have occurred in the last two decades in the characteristics of the immigrant population, the level of education is particularly important. Overall, 10 percent of the Canadian population in 1986 had a university degree, 44.5 percent had a high school diploma or better, and 18.2 percent had less than a grade nine education. Table 2 shows that there was considerable variation by age, sex, birthplace and period of immigration. Among the foreign born, males who arrived in the decade 1967-77 were the best educated-almost one in five had a degree. With a

\footnotetext{
2 Traditional source countries are Britain, Europe and the United States; nontraditional sources are all other countries including those in Asia, Africa, the Caribbean and Latin America.

3 For example, throughout the 1970 s and 1980 s, unemployment rates in Newfoundland were 2 to 4.5 times the rate in Metropolitan Toronto. In rural areas of Newfoundland they were even higher. In 1985 , they were $24 \%$ compared with $6.7 \%$ in Metropolitan Toronto.
} 
TABLE 1

ETHNIC ORIGINa ${ }^{\mathrm{a}}$ BY BIRTHPLACE AND PERIOD OF IMMIGRATION

\begin{tabular}{|c|c|c|c|c|c|c|c|c|}
\hline & & & & & & of Immigx & & \\
\hline & Total & Nonimmig ${ }^{b}$ & Immig & 1946 & $1946-66$ & $1967-77$ & $1978-82$ & $1983-86$ \\
\hline British & $6,332,720$ & $5,527,930$ & 804,790 & 178,535 & 338,580 & 205,520 & 62,885 & 18,230 \\
\hline$\%$ & 25.3 & 26.2 & 20.6 & 43.9 & 21.7 & 16.9 & 13.0 & 7.5 \\
\hline French & $6,093,165$ & $6,002,785$ & 90,380 & 15,575 & 32,195 & 29,160 & 9,005 & 4,450 \\
\hline$\%$ & 24.4 & 28.4 & 2.3 & 3.8 & 2.1 & 2.4 & 1.9 & 1.8 \\
\hline German & 895,715 & 645,540 & 251,175 & 32,550 & 169,790 & 30,775 & 10,830 & 7,235 \\
\hline$\%$ & 3.6 & 3.1 & 6.4 & 8.0 & 10.9 & 2.5 & 2.2 & 3.0 \\
\hline Italian & 709,590 & 339,535 & 370,055 & 10,195 & 281,880 & 58,400 & 7,140 & 2,445 \\
\hline$\%$ & 3.6 & 1.6 & 9.5 & 2.5 & 18.1 & 4.8 & 1.5 & 3.0 \\
\hline Portuguese & 199,595 & 55,205 & 144,390 & 355 & 40,830 & 84,340 & 11,295 & 5,435 \\
\hline$\%$ & 0.8 & .3 & 3.7 & .1 & 2.6 & 6.9 & 2.3 & 2.2 \\
\hline Chinese & 369,320 & 93,330 & 266,990 & 2,215 & 34,375 & 105,710 & 81,330 & 40,360 \\
\hline$\%$ & 1.5 & .4 & 6.8 & .5 & 2.2 & 8.7 & 16.9 & 16.6 \\
\hline South Asian & 265,890 & 68,545 & 144,390 & 315 & 11,640 & 120,315 & 42,470 & 23,515 \\
\hline$\%$ & 1.1 & .3 & 3.7 & .1 & .7 & 9.9 & 8.8 & 9.6 \\
\hline Other single origins & $\mathbf{3}, 176,760$ & $1,877,580$ & $1,299,080$ & 115,375 & 479,980 & 397,525 & 192,040 & 113,150 \\
\hline$\%$ & 12.7 & 8.9 & 33.2 & 28.4 & 30.8 & 32.6 & 39.9 & 46.4 \\
\hline Multiple origins & $6,785,345$ & $6,503,310$ & 483,035 & 50,130 & 187,230 & 173,880 & 62,810 & 26,880 \\
\hline$\%$ & 27.1 & 30.8 & 12.4 & 12.3 & 12.0 & 14.3 & 13.0 & 11.0 \\
\hline TOTAL & $25,010,995$ & $21,113,855$ & $3,908,145$ & 406,300 & $1,557,555$ & $1,218,710$ & 481,885 & 243,705 \\
\hline$\%$ & 100.0 & 100.0 & 98.6 & 99.7 & 101.2 & 98.9 & 99.6 & 101.1 \\
\hline
\end{tabular}

Source: Statistics Canada, Census of Canada, 1986. Profile of Immigrants, Cat. 93-155. Table 1.

Notes: a Ethnic origin is based on question 17 in the $\mathrm{n} 1986$ Census of Canada which read "To which ethnic or cultural group(s) do you or did your ancestors belong? Mark or specify as many as applicable." There were fifteen pre-selected categories and room for three other write-in descriptions. A Note in the Census Guide indicated that ethnic or cultural group referred to "roots" and should not be confused with citizenship or nationality. in Canada

b Nonimmig is defined as persons born in Canada, excluding those whose parents were diplomatic or military personnel temporarily resident

c Imm is defined as persons born outside Canada, excluding those who acquired Canadian citizenship by birth.

not all columns sum to total due to rounding and omission of 'not known.' 
TABLE 2

Population 15 Years and OVer Highest LeVel of Schooling by SeX, Birthplace and Pertod of Immigration

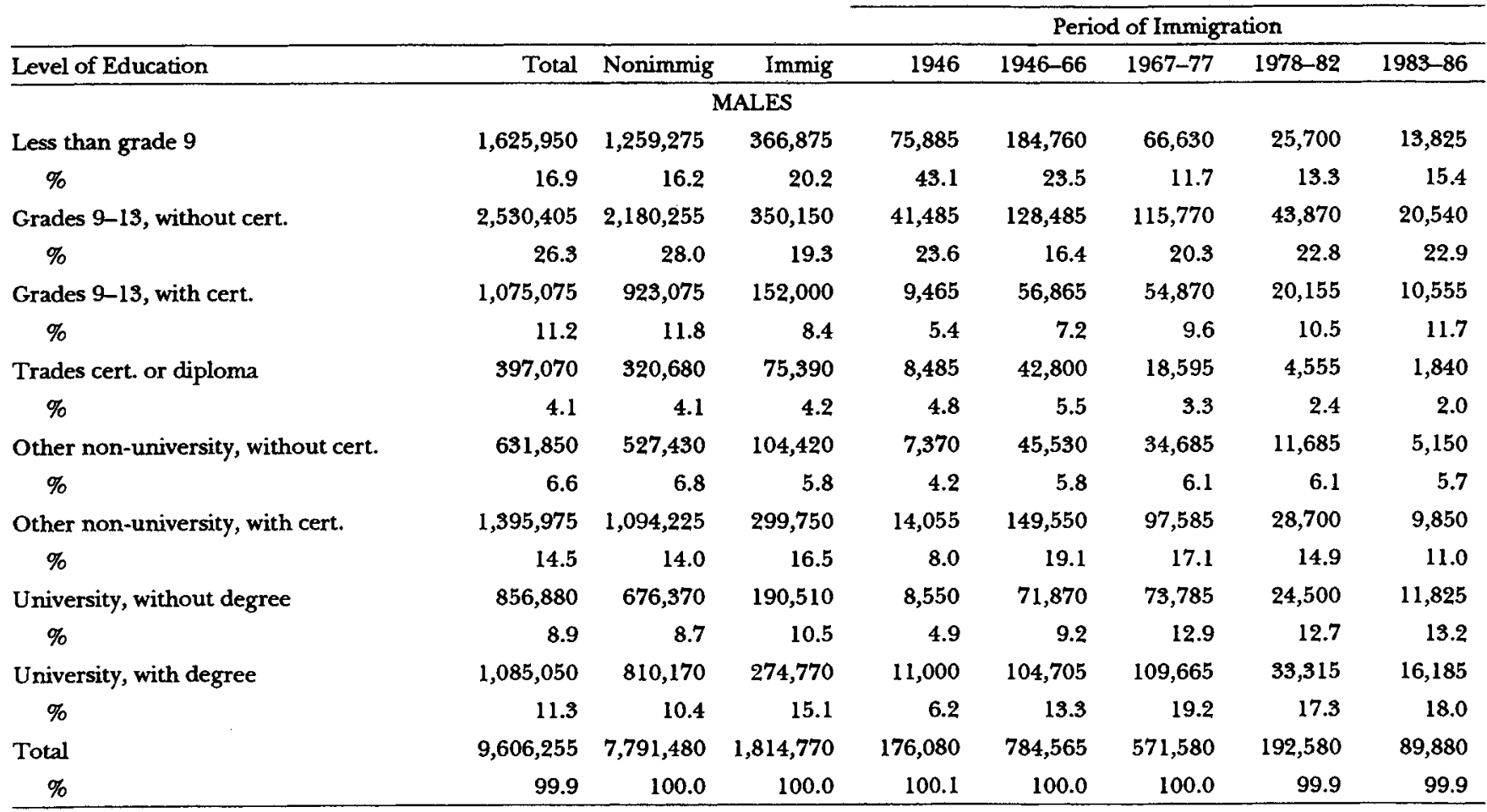


TABLE 2

(Continued)

\begin{tabular}{|c|c|c|c|c|c|c|c|c|}
\hline \multirow[b]{2}{*}{ Level of Education } & \multirow[b]{2}{*}{ total } & \multirow[b]{2}{*}{ Nonimmg } & \multirow[b]{2}{*}{ Immig } & \multicolumn{5}{|c|}{ Period of Immifration } \\
\hline & & & & $<-1946$ & $1946-66$ & $1967-77$ & 1978-82 & $1983-86$ \\
\hline \multicolumn{9}{|c|}{ FEMALES } \\
\hline Less than grade 9 & $1,757,775$ & $1, \mathbf{2 7 4 , 8 8 0}$ & 498,090 & 101,845 & 222,320 & 104,190 & 41,815 & 23,120 \\
\hline$\%$ & 17.5 & 15.7 & 25.9 & 44.2 & 28.8 & 17.9 & 20.1 & 22.6 \\
\hline Grades 9-13, without cert. & $2,790,825$ & $2,353,190$ & 437,635 & 64,280 & 172,315 & 130,105 & 48,235 & 22,695 \\
\hline$\%$ & 27.8 & 29.0 & 23.0 & 27.9 & 22.3 & 22.4 & 23.2 & 22.2 \\
\hline Grades 9-13, with cert. & $1,435,145$ & $1,217,420$ & 218,725 & 16,770 & 89,875 & 72,425 & 26,520 & 13,135 \\
\hline$\%$ & 14.3 & 15.0 & 11.5 & 7.3 & 11.6 & 12.5 & 12.8 & 12.8 \\
\hline Trades cert. or diploma & 204,430 & 170,720 & 33,705 & 2,535 & 15,150 & 10,780 & 3,590 & 1,640 \\
\hline$\%$ & 2.0 & 2.1 & 1.8 & 1.1 & 2.0 & 1.9 & 1.7 & 1.6 \\
\hline \multicolumn{2}{|c|}{ Other non-university, without cert. 705,870} & 584,940 & 118,935 & 12,830 & 46,930 & 38,735 & 13,330 & 6,110 \\
\hline$\%$ & 7.0 & 7.2 & 6.2 & 5.6 & 6.1 & 6.7 & 6.4 & 6.0 \\
\hline Other non-university, with cert. & $1,459,695$ & $1,202,550$ & 250,940 & 15,655 & 108,470 & 92,320 & 27,975 & 11,520 \\
\hline$\%$ & 14.6 & 14.8 & 13.2 & 6.8 & 14.0 & 15.9 & 13.5 & 11.3 \\
\hline University, without degree & 871,780 & 705,315 & 160,470 & 9,535 & 57,730 & 65,450 & 21,780 & 10,880 \\
\hline$\%$ & 8.7 & 8.7 & 8.4 & 4.1 & 7.5 & 11.3 & 10.5 & 10.6 \\
\hline University, with degree & 793,430 & 614,655 & 178,780 & 5,870 & 60,194 & 74,810 & 24,610 & 13,290 \\
\hline$\%$ & 7.9 & 7.6 & 9.4 & 2.5 & 7.8 & 12.9 & 11.8 & 13.0 \\
\hline Total & $10,027,845$ & $8,123,565$ & $1,904,285$ & 230,220 & 772,890 & 580,815 & 207,855 & 102,395 \\
\hline$\%$ & 99.9 & 100.0 & 99.4 & 99.6 & 100.0 & 101.4 & 100.0 & 100.0 \\
\hline
\end{tabular}

Source:Statistics Canada, 1986 Census of Canada, Profile of Immigrants: Cat 93-155, Table 1. 
growing emphasis on family reunion, and the admission of refugees, there has been a decline in the number and proportion of highly selected independent immigrants in the last decade. As a result, there is evidence of a less well-educated stream, most marked among recently arrived women. However, even among the 1983-86 cohort, the level of education of males is generally above the Canadian average. In this group of immigrant women, there is some clustering at the highest and lowest ends of the scale.

\section{ECONOMIC DIMENSIONS}

In the first fifteen years after World War II (1946-61), the total labor force of Canada increased by 1.9 million and postwar immigration accounted for 42 percent of that growth. In the following decade (1961-71) another 2.15 million workers were added, and net immigration accounted for 16.4 percent of that growth. Between 1971 and 1981, net immigration accounted for 20 percent of the growth of over 3.5 million, but in the next five years (1981-86) there was a slight decline in the number of immigrants in the labor force, despite the addition of approximately 175,000 workers who had immigrated in that period. This was a consequence of the remigration, retirement and mortality of the earlier cohorts. By far, the largest single source of growth in the labor force in recent years has been the increased labor force participation rates of Canadian-born women which, on an age-standardized basis, rose from 39 percent in 1971 to 55.4 percent in 1986-still slightly below that of immigrant women (57.8\%).

\section{Structural Change}

Detailed analyses of 1971 census data led to the conclusion that no single theoretical model of immigrant adaptation and incorporation of the foreign born into the economy could explain the complex distribution of immigrants in the industrial and occupational system of Canada (Richmond and Kalbach, 1980; Richmond and Zubrzycki, 1984). Functionalist theories, ethnic pluralism, class conflict, colonial and labor market segmentation models all received some support when partial and limited aspects of the phenomenon were considered. However, one aspect of the experience of immigrants between 1951 and 1971 was highlighted, namely, the influence of postindustrial development and structural changes taking place in the distribution of workers by industry. It was found that, generally speaking, immigrants avoided the declining primary sector and that an increasing proportion of those arriving before 1971 had entered the expanding secondary and tertiary sectors, lending support to a "structural change" model 


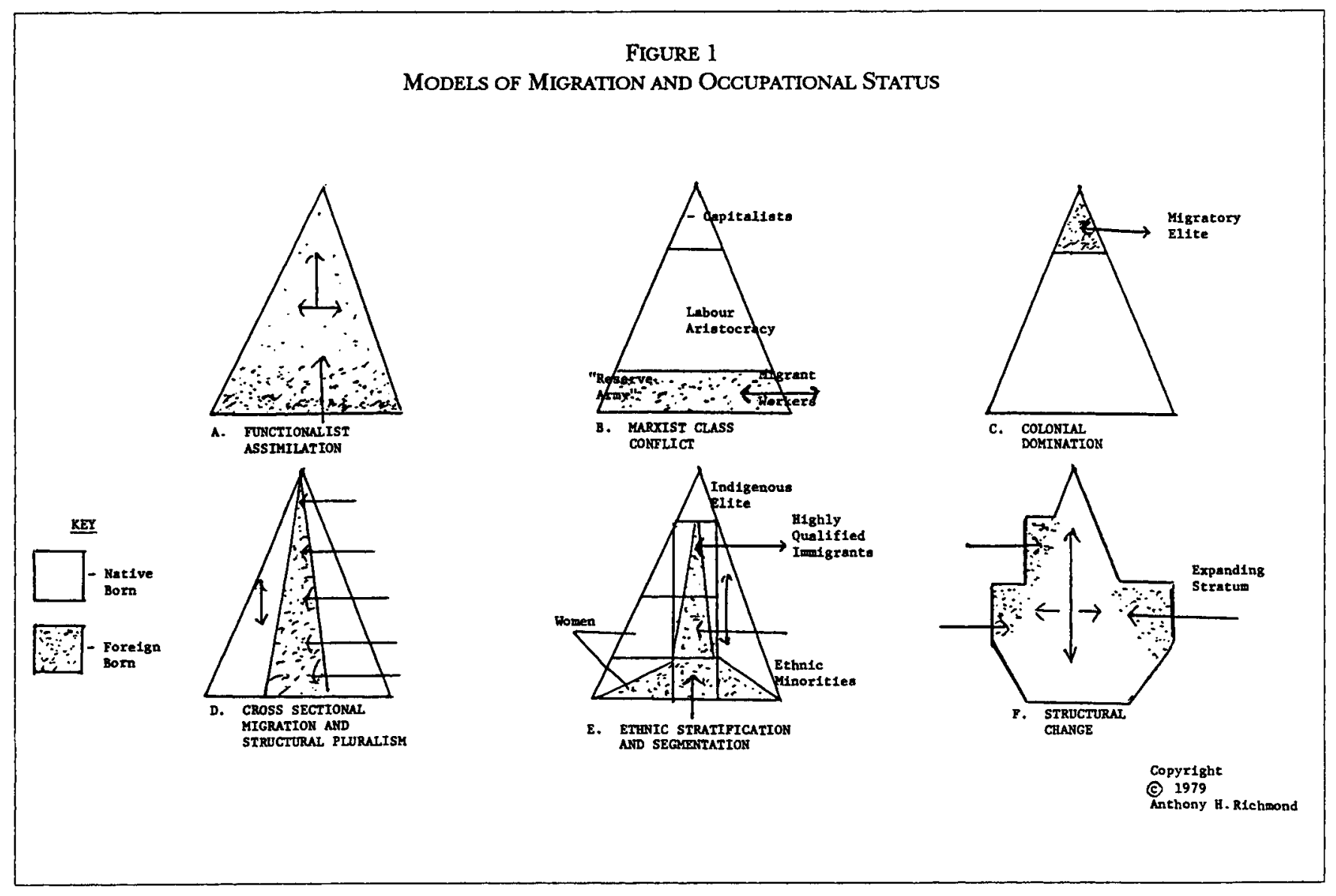


of immigrant absorption. The various theoretical models of immigrant adaptation and occupational status are illustrated in Figure I. ${ }^{4}$

The Canadian experience, in the years following 1971, continues to lend support to the importance of structural change, while at the same time reinforcing the conclusion that in order to arrive at even a "rough approximation to the complex realities of immigration" no single theoretical perspective is adequate and that "the institutional structures of receiving societies, already experiencing exogenous pressure to change and to respond to worldwide economic forces and technological innovations, react also to endogenous pressures which emanate from demographic sources"(Richmond and Zubrzycki, 1984:133). Analyses of 1981 census data for Canada confirmed that no one model was adequate to explain the occupational distribution of immigrants and their income levels. It was necessary to distinguish the experience of those who came from traditional source countries from others, to differentiate between men and women, and to take into account the effect of length of residence and the auspices of immigration. Beaujot et al. (1988:88) noted that immigrants might include "an American engineer recruited to work in a Canadian subsidiary, an Indochinese refugee rescued from the boats leaving Vietnam and a teacher who arrived from the Netherlands as a very young child some thirty years ago." No one theory could explain the experience of all.

Although processes of structural change alone may not be able to explain all the trends in immigrant adaptation, shifts in the distribution of a much expanded labor force, 1971-86, have an important bearing on the process of absorption. Table 3 shows the pattern of structural change that occurred in the Canadian labor force by industry in this period. Overall, the labor force grew by nearly 4 million people. The primary sector (agriculture, mining etc.) only added 6 percent compared with a growth of 17 percent in the secondary (mainly manufacturing) industries. By far the most rapid expansion was in the tertiary sector $(69 \%)$. Some industries that were expanding up to 1971 have since begun to decline, but only tobacco, leather and textiles experienced an absolute decline in the fifteen-year period. Clothing and textiles survived largely through tariff protection. Some, such as agriculture, fishing, oil exploration and rail transportation, benefited from direct government subsidies, supply management and tax incentives.

Table 4 shows the percentage distribution and relative concentration of immigrants by industrial sector, comparing males and females and those

\footnotetext{
4 Prepared by the present author in 1979 and used for teaching purposes, the models were first published in Richmond and Zubrzycki (1984). They have since been reproduced and/or discussed in Beaujot et al. (1988); Verma and Basavarajappa, (1989); and Seward and Tremblay (1989; 1990).
} 
TABLE 3

STRUCTURAL CHANGE IN EMPLOYMENT BY INDUSTRY: 1971-1986

\begin{tabular}{|c|c|c|c|c|}
\hline Industries $^{2}$ & $\begin{array}{c}\text { Employment } \\
1971\end{array}$ & $\begin{array}{c}\text { Employment } \\
1986\end{array}$ & $\begin{array}{c}\text { Change } \\
1971-1986\end{array}$ & $\begin{array}{l}\% \text { Change } \\
1971-1986\end{array}$ \\
\hline Total & 7584396 & 11569900 & 3985504 & 52.55 \\
\hline All Primary & 703295 & 748240 & 44945 & 6.39 \\
\hline All Secondary & 2195296 & 2571320 & 376024 & 17.13 \\
\hline All Tertiary & 4685805 & 7908745 & 3222940 & 68.78 \\
\hline \multicolumn{5}{|l|}{ Secondary } \\
\hline Food \& Beverages & 220694 & 264625 & 43931 & 19.91 \\
\hline Tobacco Products & 9582 & 6950 & -2632 & -27.47 \\
\hline Rubber \& Plastics & 44928 & 70135 & 25207 & 56.11 \\
\hline Leather Industries & 28017 & 22185 & -5832 & -20.82 \\
\hline Primary Textiles & 69487 & 21290 & -48197 & -69.36 \\
\hline Textile Products & 23948 & 34685 & 10737 & $\mathbf{4 4 . 8 3}$ \\
\hline Clothing Industries & 99516 & 122170 & 22654 & 22.76 \\
\hline Wood Industries & 93040 & 121960 & 28920 & 31.08 \\
\hline Furniture \& Fixtures & 44580 & 65955 & 21375 & 47.95 \\
\hline Paper \& Allied & 119102 & 123265 & 4163 & 3.50 \\
\hline Printing \& Publishing & 85862 & 141260 & 55398 & 64.52 \\
\hline Primary Metal & 112889 & 113055 & 166 & .15 \\
\hline Metal Fabricating & 138992 & 152265 & 13273 & 9.55 \\
\hline Machinery & 71441 & 75695 & 4254 & 5.95 \\
\hline Transportation Equipment & 150597 & 211705 & 61108 & 40.58 \\
\hline Electrical Products & 123450 & 148600 & 25150 & 20.37 \\
\hline Nonmetallic Mineral & 51925 & 54690 & 2765 & 5.32 \\
\hline Petroleum \& Coal & 14056 & 22980 & 8924 & 63.49 \\
\hline Chemical & 77445 & 94795 & 17350 & 22.40 \\
\hline Miscellaneous Manufacturing & 57971 & 85955 & 27984 & 48.27 \\
\hline Construction & 557774 & 617085 & 59311 & 10.63 \\
\hline \multicolumn{5}{|l|}{ Tertiary } \\
\hline Transportation \& Storage & 376319 & 537145 & 160826 & 42.74 \\
\hline Communications & 144003 & 229705 & 85702 & 59.51 \\
\hline Electric \& Other Utilities & 63523 & 126585 & 63062 & 99.27 \\
\hline Wholesale trade & 343942 & 524330 & 180388 & 52.45 \\
\hline Retail trade & 929854 & 1385270 & 455416 & 48.98 \\
\hline Finance, Insurance \& Real Estate & 336183 & 632920 & 296737 & 88.27 \\
\hline Business Services & 267943 & 545285 & 277342 & 103.51 \\
\hline Government Services & 639585 & 874815 & 235230 & 36.78 \\
\hline Education & 569485 & 773915 & 204430 & $\mathbf{3 5 . 9 0}$ \\
\hline Health \& Welfare & 513095 & 940555 & 427460 & 83.31 \\
\hline Amusement \& Recreation & 45351 & 132380 & 87029 & 191.90 \\
\hline Accommodation \& Food & 297922 & 662410 & 364488 & 122.34 \\
\hline Other Personal \& Miscellaneous & 158600 & 543430 & 384830 & 242.64 \\
\hline
\end{tabular}

Source: Statistics Canada, Census 1971 and 1986.

Note: a Excluding "Other" and not specified. 
TABLE 4

Percentage Distribution and Index Relative Concentration of ImmigRants by INdustrial Sector

\begin{tabular}{|c|c|c|c|c|c|c|c|c|c|c|c|}
\hline & Total L.F. ${ }^{\mathbf{a}}$ & a Nonimm $b$ & All $\mathrm{Imm}^{\mathrm{c}}$ & $\operatorname{Trad}^{\mathrm{d}}$ & $\begin{array}{l}\text { Long } \\
<1971\end{array}$ & $\begin{array}{c}\text { Inter } \\
1971-80 \\
\end{array}$ & $\begin{array}{c}\text { Recent } \\
1981-86 \\
\end{array}$ & Non Trad ${ }^{e}$ & $\begin{array}{l}\text { Longf } \\
<1971 \\
\end{array}$ & $\begin{array}{c}\text { Inter } \\
1971-80\end{array}$ & $\begin{array}{l}\text { Recentg } \\
1981-86\end{array}$ \\
\hline \multicolumn{12}{|c|}{ MALES } \\
\hline Primary $\%$ & 9.2 & 10.2 & 4.8 & 5.8 & 5.7 & 5.5 & 6.8 & 2.6 & 2.6 & 2.4 & $\mathbf{3 . 0}$ \\
\hline Index & 100.0 & 110.9 & 52.2 & 63.0 & 62.0 & 59.8 & 73.9 & 28.3 & 28.3 & 26.1 & 32.6 \\
\hline Secondary $\%$ & 30.6 & 29.2 & 37.0 & 39.1 & 39.0 & 39.6 & 38.5 & 32.4 & 26.3 & 34.7 & 35.7 \\
\hline Index & 100.0 & 95.4 & 120.9 & 127.8 & 127.5 & 129.4 & 125.8 & 105.9 & 85.9 & 113.4 & 116.7 \\
\hline Tertiary \% & 60.2 & 60.7 & 58.2 & 55.1 & 55.2 & 54.9 & 54.6 & 65.1 & 71.0 & 62.9 & 61.3 \\
\hline Index & 100.0 & 100.8 & 96.7 & 91.5 & 91.7 & 91.2 & 90.7 & 108.1 & 117.9 & 104.5 & 101.8 \\
\hline \multicolumn{12}{|c|}{ FEMALES } \\
\hline Primary \% & 3.6 & 3.8 & 3.0 & 3.4 & 3.5 & 3.2 & 4.2 & 2.2 & 1.6 & 2.2 & 3.3 \\
\hline Index & 100.0 & 105.6 & 83.3 & 94.4 & 97.2 & 88.9 & 116.7 & 61.1 & 44.4 & 61.1 & 91.7 \\
\hline Secondary \% & 13.2 & 11.7 & 20.2 & 19.4 & 19.4 & 19.8 & 17.8 & 21.9 & 13.4 & 23.7 & 30.2 \\
\hline Index & 100.0 & 88.6 & 153.0 & 147.0 & 147.0 & 150.0 & 134.8 & 165.9 & 101.5 & 179.5 & 228.8 \\
\hline Tertiary \% & 83.1 & 84.6 & 76.7 & 77.2 & 77.2 & 77.0 & 78.0 & 75.9 & 85.0 & 74.1 & 66.5 \\
\hline Index & 100.0 & 101.8 & 92.3 & 92.9 & 92.9 & 92.7 & 93.9 & 91.3 & 102.3 & 89.2 & 80.0 \\
\hline
\end{tabular}

Source: Statistics/IRPP, Special Tabulations, 1986 Census of Canada, adapted from Seward, 1989.

Notes a L.F. is labor Force.

b Nonimmig is defined as persons born in Canada, excluding those whose parents were diplomatic or military personnel temporarily resident in Canada.

c Imm is defined as persons born outside Canada, excluding those who acquired Canadian citizenship by birth.

d Trad is defined as immigrants from traditional source countries i.e. Britain, Europe and the USA

e Non Trad is defined as all other source countries.

$f$ Long are immigrants arriving before 1971 .

8 Recent are immigrants arriving 1981-86. 
from traditional and nontraditional source countries by period of immigration. The data confirm the continued underrepresentation of immigrants in the primary sector (although this is more true of men than women). It also confirms the relative concentration of immigrants, from both traditional and nontraditional sources, in the secondary (mainly manufacturing and construction) industries. Males from nontraditional source countries are also overrepresented in the tertiary sector. However, immigrant women exhibit the greatest degree of overrepresentation in the secondary manufacturing sector. This is particularly true of the most recent arrivals from nontraditional source countries. With the exception of the long term immigrants from nontraditional sources, foreign-born women are underrepresented in tertiary industries.

Further light is thrown on the question of immigration and structural change when the distribution of immigrants in the fastest growing industries is compared with that in declining sectors (Table 5). The seven fastest growing industrial subsectors between 1971 and 1986 were business services, finance insurance and real estate, accommodations and food services, health and welfare (social services), amusement and recreation, and "other" personal and miscellaneous services. Altogether, they accounted for 43 percent of the total labor force in 1986 and almost half of the immigrants from nontraditional source countries. The relative concentration of immigrants was greatest in the accommodation and food services sector, business services and in finance, insurance and real estate. Only in accommodation and food services, together with business services, were the most recently arrived immigrants from nontraditional source countries overrepresented. However, as shown in Table 5, there was also some overrepresentation of immigrants in declining industries such as leather and textiles, but these accounted for only .5 percent of the total labor force and only 1.1. percent of the most recent immigrants. It must be noted that accommodations and food services, while growth industries in terms of employment, are also subject to seasonal fluctuations, high unemployment and traditionally low wages. They are at the unskilled end of the expanding service sector, employing many immigrant women. This industry contrasts with business services, where immigrants also are overrepresented, but which are part of the "high-tech" expansion in computers and communications technology, characteristic of postindustrial societies.

Structural changes in the industrial distribution of the labor force accelerated in the mid-1970s and, by 1981, some industries began to decline in terms of the absolute numbers employed. The decline continued between 1981 and 1986 and was evident in a number of secondary industries, notwithstanding some overall growth (albeit slow) over the longer period, 
TABLE 5

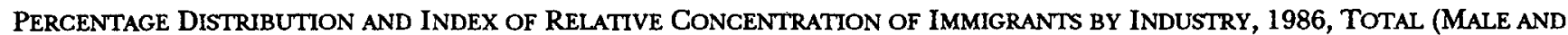
FEMALE) BY SPECIFIC INDUSTRIES

\begin{tabular}{|c|c|c|c|c|c|c|c|c|c|c|c|}
\hline & Total L.F. ${ }^{\mathbf{a}}$ & onimm & $11 \mathrm{Imm}^{\mathrm{C}}$ & $\operatorname{Trad}^{\mathrm{d}}$ & $\begin{array}{l}\text { Long } \\
<1971 \\
\end{array}$ & $\begin{array}{c}\text { Inter } \\
1971-80 \\
\end{array}$ & $\begin{array}{c}\text { Recent } \\
1981-86 \\
\end{array}$ & Non Trad & $\begin{array}{l}\text { Longf } \\
<1971 \\
\end{array}$ & $\begin{array}{c}\text { Inter } \\
19971-80 \\
\end{array}$ & $\begin{array}{c}\text { Recent }^{g} \\
1981-86 \\
\end{array}$ \\
\hline \multicolumn{12}{|l|}{ Declining Labor Force } \\
\hline Tobacco Products \% & .1 & .1 & .1 & .1 & .1 & .0 & .0 & .1 & .1 & .0 & .0 \\
\hline Index & 100.0 & 100.0 & 100.0 & 100.0 & 100.0 & .0 & .0 & 100.0 & 100.0 & .0 & .0 \\
\hline Leather prod. \% & .2 & & .4 & & .4 & .6 & .5 & .4 & .1 & .5 & .8 \\
\hline Index & 100.0 & 100.0 & 200.0 & 200.0 & 200.0 & 300.0 & 250.0 & 200.0 & 50 . & 250.0 & 400.0 \\
\hline ary textiles $\%$ & & & & & & .2 & .2 & & .1 & .2 & .3 \\
\hline Inder & 100.0 & 100.0 & 100.0 & 100.0 & 100.0 & 100.0 & 100.0 & 100.0 & 50. & 100.0 & 150.0 \\
\hline sub-total \% & .5 & & & & .7 & .8 & .7 & .7 & .3 & .7 & 1.1 \\
\hline \multicolumn{12}{|l|}{ Fast Growing Labor Force } \\
\hline Utilities & 1.1 & 1.1 & .9 & 1.0 & 1.1 & .7 & .4 & .6 & 1.1 & .6 & .2 \\
\hline Ind & 100.0 & 100.0 & 81.8 & 90.9 & 100.0 & 63.6 & 36.4 & 54.5 & 100.0 & 54.5 & 18.2 \\
\hline less serv. $\%$ & 4.6 & 4.5 & 5.2 & 5.1 & 4.8 & 5.5 & 7.0 & 5.5 & 6.1 & 5.3 & 4.8 \\
\hline & 100.0 & 97.8 & 113.0 & 110 & 104.3 & 119.6 & 152.2 & 119.6 & 132.6 & 115.2 & 104.3 \\
\hline Fin. Ins. \& Real Est. & 5.4 & 5.4 & 5.7 & 5.3 & 5.5 & 5.0 & 4.3 & 6.4 & 6.7 & 7.1 & 4.1 \\
\hline & 100.0 & 100.0 & 105.6 & 98. & 101.9 & 92.6 & 79.6 & 118.5 & 124.1 & 131.5 & 75.9 \\
\hline Accom. \& Food ser. \% & 6.3 & 6.0 & 7.7 & 6.1 & 5.4 & 8.6 & 8.4 & 10.9 & 8.2 & 10.8 & 15.4 \\
\hline & 100.0 & 95.2 & 122.2 & 96.8 & 85.7 & 136.5 & 133.3 & 173.0 & 130.2 & 171.4 & 244.4 \\
\hline Health \& Welfare & 8.2 & 8.2 & 8.1 & & 7.1 & 7.5 & 8.1 & 9. & 13.5 & 9.5 & 5.5 \\
\hline 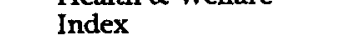 & 100.0 & 100.0 & 98.8 & 87 & 86.6 & 91.5 & 98.8 & 120.7 & 164.6 & 115.9 & 67.1 \\
\hline Amuse \& Rec. & 4.6 & 4.7 & 4.3 & 4 & 4.3 & 4.0 & 4.2 & 4.5 & 4.2 & 4.3 & 4.5 \\
\hline ב & 100.0 & 102.2 & 93.5 & 91.3 & 93.5 & 87.0 & 91.3 & 93.5 & 91.3 & 93.5 & 97.8 \\
\hline Other Pers. \& Misc. & 12.6 & 12.9 & 11.1 & 11.0 & 11. & 11.1 & 10.2 & 11. & 10.5 & 12.0 & 11.6 \\
\hline Index & 100.0 & 102.4 & 88.1 & 87.3 & 87.3 & 88.1 & 81.0 & 91.3 & 83.3 & 95.2 & 92.1 \\
\hline Sub-total \% & 42.8 & 42.8 & 43.0 & 39.9 & 39.2 & 42.4 & 42.6 & 49.1 & 50.3 & 49.6 & 46.1 \\
\hline
\end{tabular}

Source: Statistics Canada/IRPP, Special Tabulations, 1986 Census of Canada, adapted from Seward \& Tremblay, 1989

Notes a $\quad$ L.F. is labor Force.

b Nonimmig is defined as persons born in Canada, excluding those whose parents were diplomatic or military personnel temporarily resident in Canada.

c Imm is defined as persons born outside Canada, excluding those who acquired Canadian citizenship by birth.

d Trad is defined as immigrants from traditional source countries i.e. Britain, Europe and the USA.

e Non Trad is defined as all other source countries.

Long are immigrants arriving before 1971 .

$g$ Recent are immigrants arriving 1981-86. 
1971-86, which occurred mainly in the early part of the decade. In fact, almost all secondary industries experienced some loss of employment in the quinquennium 1981-86, when the overall decline in that sector was -5 percent. The largest losses were in metals, machinery, wood, paper and primary textiles. A recent monograph, based on the 1986 census, examined the relevance of the aforementioned theoretical models and tested the hypothesis that structural change is important in explaining the occupational and industrial distribution of immigrants in Canada (Seward and Tremblay, 1989). More support was found for the structural change model in respect of male immigrants than for females. Men from nontraditional source countries had higher levels of education and were responding to the needs of rapidly expanding industries, whereas recently arrived immigrant women from similar countries were not responding as effectively to changing labor markets as nonimmigrant women, although both were overrepresented in low paid jobs in the expanding service sector (Seward and Tremblay, 1989:36). A further analysis found that rapidly growing industries had a more highly educated labor force with better official language skills, but no clear association between growth and employment income (Seward and Tremblay, 1990:19).

\section{Occupations and Incomes}

The economic aspects of immigrant absorption and the effect of structural change can be further analyzed by an examination of occupational distributions. Marr (1986:770-771) showed that, in 1981, foreign-born males were proportionally overrepresented in nine out of the twelve fastest growing occupations for men, and immigrant females were proportionally overrespresented in seven out of sixteen fastest growing occupations for women. However, the most recently arrived were somewhat less likely to follow this trend than those who had arrived before 1971 . When the total foreign-born population is considered, there are few significant differences between it and the Canadian born, except those that would be expected given the small number of immigrants in rural areas and primary industries. However, when specific birthplace was taken into account, male immigrants (in 1981) from the United States, Great Britain, western Europe and Asia were overrepresented in professional and managerial occupations, while those from southern Europe were relatively concentrated in manufacturing and construction. Immigrant women tended to be in services and product fabricating, and this was particularly true of those from southern Europe (Beaujot et al., 1988:40-44). The effect of length of residence on occupational distributions (in 1986) is shown in Table 6. It is evident that the most recently arrived immigrants are overrepresented in product fabricating and 
in service occupations, confirming the evidence of numerous previous studies that, notwithstanding high educational qualifications and occupational selection, immigrants frequently do not pursue their intended occupations during their first few years in Canada (Richmond, 1967; Manpower and Immigration, 1974; Beaujot et al., 1988). Language difficulties and nonrecognition of qualifications are contributory factors in this initial adjustment period.

Evidence from the 1971 census suggested that, notwithstanding early adjustment difficulties and set-backs, immigrants eventually recovered and generally surpassed the Canadian born in terms of income (Richmond and Kalbach, 1980). This continues to be the case. In 1980, unadjusted immigrant male incomes were $\$ 18,553$ compared with $\$ 16,577$ for Canadianborn men; the equivalent figures for women were $\$ 8,872$ and $\$ 8,322$, respectively (Beaujot et al., 1988:49). In 1985, median total incomes were $\$ 19,797$ for males and $\$ 9,540$ for females (Statistics Canada, 1989: Table 1). The distribution by sex, birthplace and period of immigration is shown in Table 7. Although median incomes of postwar immigrants, who had been in the country ten years or more, exceeded those of the Canadian born, more recent immigrants fell below the average. Males who arrived 1983-86 received only $\$ 9,323$ and females received $\$ 8,219$. Male immigrants in 1970 had arithmetic average total incomes that were 7.7 percent above those of the Canadian born, 12.8 percent higher in 1980 and 11.8 percent above in 1985. The average for female immigrants was about the same in 1970, but 6.7 percent above in 1980 and 5.6 percent higher in 1985 .

Employment incomes for those working full time and part time in 1985 are also shown in Table 7. Immigrants arriving in the period 1978-86 were clearly falling below the average, whereas earlier arrivals were earning more than nonimmigrants. When overall comparisons are confined to earned incomes for those working full time for 40 weeks or more in the year, and then standardized for age and education, a different picture emerges. In 1970, the relative advantage of male immigrants persisted, with standardized earned income 2 percent above the Canadian-born average. However, in 1980 the standardized comparison fell to 1.1 percent below, and by 1985 men were 2.6 percent below their Canadian-born equivalents. Comparable figures for immigrant women were 2.2 percent above in 1970, 1.7 percent below in 1980 and no difference in 1985 (Beaujot and Rappak, 1989:59).

It seems that immigrants in Canada have lost some of their earlier advantage. A combination of cohort differences in origin and level of education, combined with increased adaptation for those having longer residence, accounts for some of the difference between earlier and later 
TABLE 6

POPULATION 15 YEARS AND OVER, IN LABOR FORCE, BY BIRTHPLACE, PERTOD OF IMMIGRATION AND OCCUPATION

\begin{tabular}{|c|c|c|c|c|c|c|c|c|}
\hline Occupational Group & Total & Nonimmig ${ }^{a}$ & Immig $^{b}$ & 1956 & $1946-66$ & $1967-77$ & $1978-82$ & $1983-86$ \\
\hline & & MALES & & & & & & \\
\hline Managerial, administrative, etc. & 919,690 & 735,375 & 184,310 & 8,400 & 98,015 & 58,905 & 13,890 & 5,105 \\
\hline$\%$ & 12.6 & 12.4 & 13.5 & 17.8 & 15.9 & 12.1 & 9.1 & 8.3 \\
\hline Professional \& related & 957,140 & 737,395 & 219,745 & 5,925 & 93,540 & 87,610 & 24,135 & 8,540 \\
\hline$\%$ & 13.1 & 12.4 & 16.1 & 12.5 & 15.1 & 18.1 & 15.8 & 13.9 \\
\hline Clerical \& related & 494,410 & 413,945 & 80,465 & 2,735 & 30,865 & 33,135 & 9,795 & 3,930 \\
\hline$\%$ & 6.8 & 7.0 & 5.9 & 5.8 & $\mathbf{5 . 0}$ & 6.8 & 6.4 & 6.4 \\
\hline Sales & 641,511 & 541,250 & 100,490 & 4,855 & 45,480 & 35,745 & 9,485 & 3,930 \\
\hline$\%$ & 8.8 & 9.1 & 7.4 & 10.3 & 7.4 & 7.4 & 6.2 & 6.4 \\
\hline Service & 742,515 & 584,355 & 158,250 & 3,760 & 59,575 & 57,370 & 26,125 & 11,325 \\
\hline$\%$ & 10.2 & 9.9 & 11.6 & 8.0 & 9.6 & 11.8 & 17.1 & 18.4 \\
\hline Primary & 575,020 & 522,015 & 53,005 & 8,415 & 24,745 & 12,125 & 5,335 & 2,380 \\
\hline$\%$ & 7.9 & 8.8 & 3.9 & 17.8 & 4.0 & 2.5 & 3.5 & 3.9 \\
\hline Processing & 597,985 & 461,730 & 136,255 & 2,385 & 58,545 & 49,850 & 18,505 & 6,980 \\
\hline$\%$ & 8.2 & 7.8 & 10.0 & 5.0 & 9.5 & 10.3 & 12.1 & 11.4 \\
\hline Product fabricating, assembling, etc. & 725,155 & 555,855 & 159,265 & $\mathbf{3 , 5 3 5}$ & 71,700 & 61,915 & 22,705 & 9,505 \\
\hline$\%$ & 9.9 & 9.4 & 11.7 & 7.5 & 11.6 & 12.8 & 14.9 & 15.5 \\
\hline Construction trades & 735,385 & 599,115 & 135,275 & 2,855 & 76,335 & 44,015 & 9,135 & 3,955 \\
\hline$\%$ & 10.1 & 10.1 & 9.9 & 6.0 & 12.4 & 9.1 & 6.0 & 6.4 \\
\hline Other occupations & 905,065 & 779,525 & 125,530 & 4,400 & 58,105 & 44,470 & 13,880 & 5,785 \\
\hline$\%$ & 12.4 & 13.1 & 9.2 & 9.3 & 9.4 & 9.2 & 9.1 & 9.4 \\
\hline All occupations & $7,294,215$ & $5,929,610$ & $1,364,605$ & 47,235 & 617,825 & 485,145 & 152,880 & 61,425 \\
\hline$\%$ & 100.0 & 100.0 & 99.1 & 100.1 & 99.8 & 100.0 & 100.1 & 100.0 \\
\hline
\end{tabular}


TABLE 6

(Continued)

\begin{tabular}{|c|c|c|c|c|c|c|c|c|}
\hline Occupational Group & Total & Nonimmig ${ }^{a}$ & Immig ${ }^{b}$ & 1956 & 1946-66 & $1967-77$ & $1978-82$ & $1983-86$ \\
\hline \multicolumn{9}{|c|}{ FEMALES } \\
\hline Managerial, administrative, etc. & 422,280 & 347,530 & $\mathbf{7 4 , 7 5 5}$ & 2,435 & 36,980 & 27,755 & 5,825 & 1,755 \\
\hline$\%$ & 7.8 & 7.8 & 7.5 & 8.9 & 9.1 & 7.1 & 4.7 & 3.7 \\
\hline Professional \& related & $1,136,740$ & 948,435 & 188,305 & 4,560 & $\mathbf{7 7 , 9 9 5}$ & 79,280 & 20,030 & 6,475 \\
\hline$\%$ & 20.9 & 21.3 & 18.9 & 16.7 & 19.2 & 20.4 & 16.2 & 13.5 \\
\hline Clerical \& related & $1,824,210$ & $1,544,185$ & 280,020 & 8,520 & 118,045 & 114,680 & 28,755 & 9,025 \\
\hline$\%$ & 33.5 & $\mathbf{3 4 . 7}$ & 28.2 & 31.2 & 29.0 & 29.5 & 23.3 & 18.9 \\
\hline Sales & 511,410 & 426,520 & 84,795 & 3,490 & $\mathbf{3 7 , 8 3 0}$ & 31,920 & 8,255 & 3,295 \\
\hline$\%$ & 9.4 & 9.6 & 8.5 & 12.8 & 9.3 & 8.2 & 6.7 & 6.9 \\
\hline Service & 874,905 & 701,310 & 173,500 & 4,280 & 63,600 & 64,890 & 27,705 & 13,120 \\
\hline$\%$ & 16.1 & 15.8 & 17.4 & 15.7 & 15.6 & 16.7 & 22.5 & 27.4 \\
\hline Primary & 136,130 & 114,150 & 21,985 & 1,815 & 9,510 & 5,730 & 3,455 & 1,475 \\
\hline$\%$ & 2.5 & 2.6 & 2.2 & 6.7 & 2.3 & 1.5 & 2.8 & 3.1 \\
\hline Processing & 129,550 & 99,055 & 30,485 & $\mathbf{5 3 0}$ & 10,935 & 12,190 & 4,940 & 1,895 \\
\hline$\%$ & 2.4 & 2.2 & 3.1 & 1.9 & 2.7 & 3.1 & 4.0 & 4.0 \\
\hline Product fabricating, assembling, etc. & 229,990 & 129,560 & 100,435 & 925 & 35,660 & 37,445 & 18,325 & 8,080 \\
\hline$\%$ & 4.2 & 2.9 & 10.1 & 3.4 & 8.8 & 9.6 & 14.9 & 16.9 \\
\hline Construction trades & 18,095 & 15,005 & 3,090 & 35 & 1,345 & 1,185 & 380 & 145 \\
\hline$\%$ & .3 & .3 & .3 & .1 & .3 & .3 & .3 & .3 \\
\hline Other occupations & 152,700 & 125,675 & 30,025 & 590 & 13,945 & 14,190 & 5,610 & 2,575 \\
\hline$\%$ & 2.8 & 2.8 & $\mathbf{3 . 0}$ & 2.2 & 3.4 & 3.6 & 4.6 & 5.4 \\
\hline All occupations & $5,446,010$ & $4,451,535$ & 994,480 & 27,280 & 406,815 & 389,250 & 123,280 & 47,845 \\
\hline
\end{tabular}

Source Statistics Canada, 1986, Census of Canada, Profile of Immigrants, Cat. 93-155, Table 1.

Notes: a Nonimmig is defined as persons born in Canada, excluding those whose parents were diplomatic or military personnel temporarily resident in Canada.

b Imm is defined as persons born outside Canada, excluding those who acquired Canadian citizenship by birth. 
TABLE 7

TOTAL AND EMPLOYMENT INCOME, 1985, BY SEX, BIRTHPLACE, AND PERIOD OF IMMIGRATION

\begin{tabular}{|c|c|c|c|c|c|c|c|c|}
\hline & \multirow[b]{2}{*}{ Total } & \multirow[b]{2}{*}{ Nonimmig ${ }^{a}$} & \multirow[b]{2}{*}{ Immig $^{\mathrm{b}}$} & \multicolumn{5}{|c|}{ Period of Immigration } \\
\hline & & & & $<1946$ & $1946-66$ & $1967-77$ & $1978-82$ & $1983-86$ \\
\hline \multicolumn{9}{|c|}{ Median Total Income, \$ } \\
\hline Males & 19,797 & 19,326 & 21,345 & 12,922 & 25,587 & 22,378 & 15,884 & 9,323 \\
\hline Females & 9,540 & 9,420 & 9,983 & 8,753 & 10,839 & 11,175 & 8,954 & 8,219 \\
\hline \multicolumn{9}{|c|}{ Average Employment Income Worked Full Year, Full Time, $\$$} \\
\hline Males & 30,504 & 30,153 & 31,843 & 33,708 & $\mathbf{3 3 , 5 7 7}$ & 31,460 & 25,559 & 21,815 \\
\hline Females & 19,995 & 20,052 & 19,721 & 20,211 & 20,882 & 19,905 & 15,817 & 13,222 \\
\hline \multicolumn{9}{|c|}{ Average Employment Income Worked Part Year, or Part Time, $\$$} \\
\hline Males & 13,474 & 12,977 & 16,070 & 15,972 & 18,931 & 14,949 & 11,576 & 8,219 \\
\hline Females & 8,012 & 7,810 & 8,897 & 9,017 & 10,055 & 8,898 & 7,479 & $\mathbf{5 , 8 8 5}$ \\
\hline $\begin{array}{l}\text { Source: } \\
\text { l. }\end{array}$ & \multicolumn{8}{|c|}{ Statistics Canada, Census of Canada, 1986, Profile of Immigrants, Cat. 93-155, Table } \\
\hline $\begin{array}{l}\text { Notes } \\
\text { were dip }\end{array}$ & \multicolumn{8}{|c|}{$\begin{array}{l}\text { Nonimmig is defined as persons born in Canada, excluding those whose parents } \\
\text { plomatic or military personnel temporarily resident in Canada. }\end{array}$} \\
\hline
\end{tabular}

immigrants. Further differences are due to the clustering of immigrants in metropolitan areas. Generally, they have retained a closely comparable level of earning capacity to that of the Canadian born as a whole, qualified only by the high cost of living (and particularly housing) in the metropolitan centers in which the majority are resident. Verma and Basavarajappa (1989:448) examined income levels for immigrants in metropolitan areas in 1980 and found that, overall, men earned 1.9 and women 5.9 percent less than the Canadian born living in those areas, but that the differences were greater when age and education were controlled. There was considerable variation by birthplace and period of immigration. Recently arrived immigrants from nontraditional source countries earned the lowest incomes. They found evidence of ethnic labor market segmentation as well as a relative concentration of immigrants in service industries. However, they concluded that "the differential labor market entry of immigrant groups is better explained by the structural pluralism model or the ethnic stratification and segmentation model" (Verma and Basavarajappa, 1989:449). 
The overall picture, based on averages for all immigrants, disguises some of the variations within the immigrant population, particularly when comparisons are made between those from traditional source countries and those from Third World countries. In 1985, among those who arrived 1975-79, standardized employment incomes for nontraditional source countries were 21.2 percent below those of traditional immigrant groups in the case of men and 10.7 percent below for women (Beaujot and Rappak, 1989). ${ }^{5}$ More recent arrivals were further disadvantaged.

The situation of Caribbean immigrants in 1980 is a specific case in point. A detailed analysis of the economic experience of Caribbean men and women in Canada (based on 1981 census data) revealed a pattern of absolute and relative deprivation, compared with other immigrants and the Canadian born (Richmond, 1989). When standardized for age and education, the employment incomes of francophone Caribbean males was only 67 percent of comparable Canadian-born men; the proportion for anglophone Caribbean males was 83 percent. Comparable figures for Caribbean women were 79 percent and 90 percent, respectively (Richmond, 1989:61). It was notable that the degree of disadvantage was greater in Montreal than in Toronto, lending support to the conclusion that Haitian immigrants in Quebec faced even greater degrees of prejudice and discrimination than their West Indian counterparts in Ontario. The study also demonstrated that Caribbean women faced the same substantial gender gap in income as other women, but that they recovered from the initial adjustment difficulties more quickly than Caribbean men. Furthermore, the data also show that the gap between actual and "expected" employment incomes (after standardizing for sex, age and education) grew wider as educational levels rose. In other words, well-educated Caribbean immigrants had greater difficulty achieving an occupational status and income comparable with their qualifications than those with less education. Those with university degrees had greater difficulty than similarly qualified immigrants from other countries (Richmond, 1989:44).

The problem of credentialism has been a persistent source of difficulty for wave after wave of immigrants in Canada who find their university degrees discounted, their professional qualifications unrecognized and their trade diplomas useless. The problem has been particularly acute in recent years, as the number of Canadian trained students entering the labor market increased and competition for jobs intensified. Refugee doctors have been specially hard hit. While being allowed to take written examinations to

5 Borjas (1988:64) also noted that the 1960-64 cohort in Canada started out at a $14.3 \%$ wage disadvantage, but for 1975-79 immigrants the wage disadvantage increased to $44.8 \%$. The greatest disadvantage was for those from Africa and Asia. 
prove their competence, often they have been refused the necessary period of hospital internship which is mandatory before they can be licensed to practice. A recent study of the barriers to the recognition of immigrant credentials concluded that these varied according to occupation, country of origin and province of settlement. Doctors, teachers, social workers, nurses and tradesmen all faced barriers. Ethnic prejudice and discrimination in hiring and promotion added to these difficulties (McDade, 1988; Cumming et al., 1989).

\section{CONCLUSION}

Is it possible to formulate a revised, composite model of immigrant adaptation in a postindustrial society, such as Canada, that accounts for the complex empirical findings of recent research? It is evident that a number of factors are involved, some of which are countervailing or even contradictory. The government encourages well-educated and qualified immigrants, but there are obstacles in the way of recognizing their credentials. "Canadian experience" is valued and preference is given to established immigrants over recent arrivals. Immigrants from nontraditional source countries are encouraged through a nondiscriminatory admission policy, but black and Asian immigrants face race prejudice and barriers to hiring and promotion. Female labor force participation has increased dramatically, and women are increasingly employed in professional, technical and managerial positions. Yet married women with children need assistance with housework and childcare if they are to work full time, creating a demand for immigrant women in low paid domestic employment. While well-qualified immigrants eventually move into better paid professional employment in expanding sectors, many of those not so qualified, or whose language skills are inadequate, appear to be a replacement population in manufacturing industries losing older workers (immigrant and nonimmigrant). Pay and working conditions in such industries are no longer attractive to a younger generation of well-educated Canadians who have entered the labor force in the last decade or so.

The resulting economic picture is a complicated one, but it may be represented, in a somewhat simplified form, by superimposing the characteristics of the "ethnic stratification and segmentation" model $E$ on the "structural change" model F. The result is diagrammatically represented in Figure II (model G) and titled the "segmented structural change model." It recognizes the existence of a corporate elite mainly consisting of indigenous managers and entrepreneurs, but including a few "business class" immigrants who bring with them capital for investment. There is also a multiway movement of highly qualified immigrants and transilient professionals who 


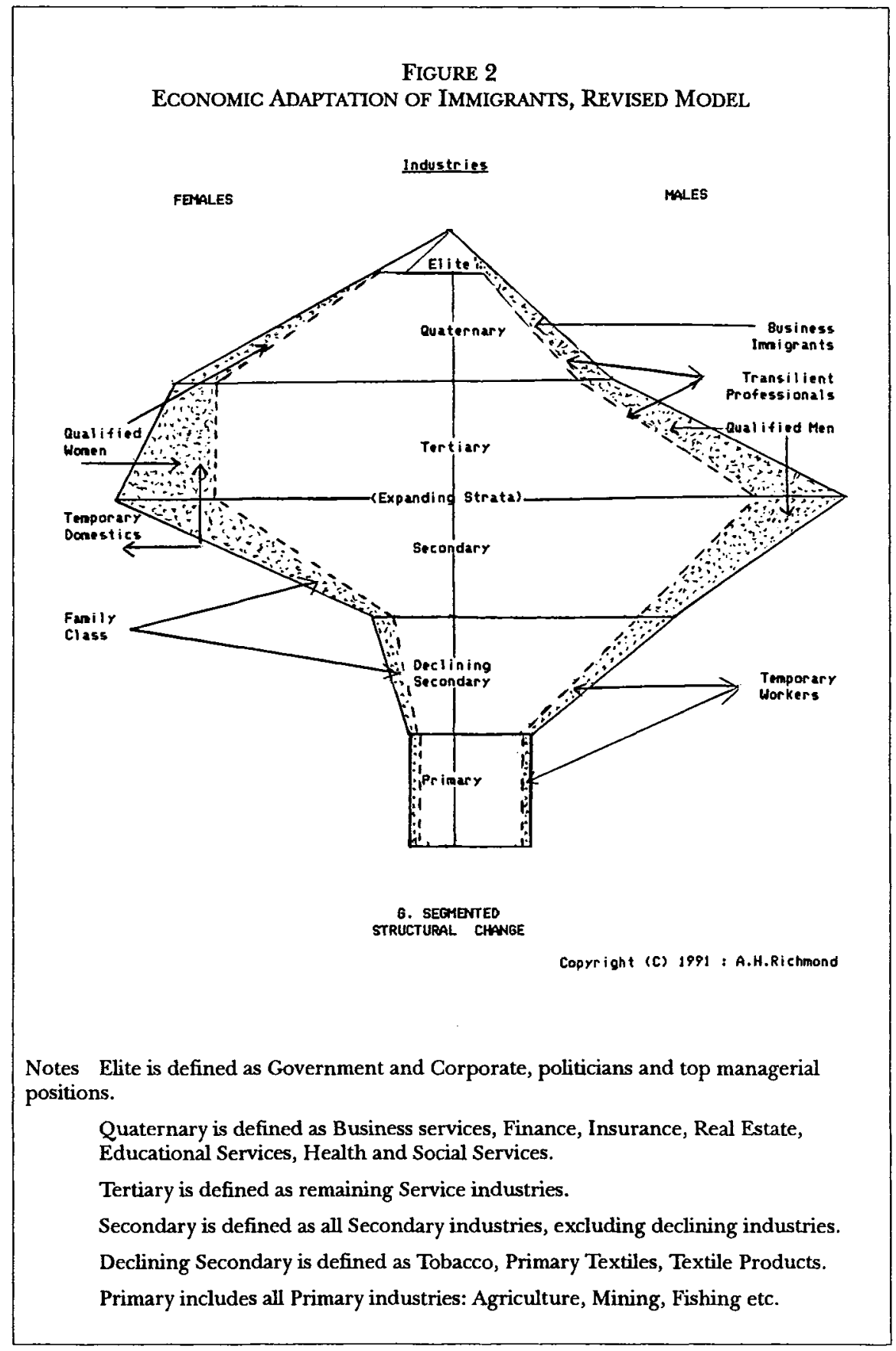


do not necessarily settle permanently but whose skills are in demand in a technologically advanced society. Expanding industries draw their labor from immigrant and nonimmigrant sources alike. Women are found at all levels of the system, but immigrant females are overrepresented in many of the poorly paid service industries and in those manufacturing industries where semiskilled manual labor is employed but a knowledge of English (or French) is not necessary. Many immigrant women are "family class," sponsored without regard to their qualifications. Some recently arrived immigrant men and women gravitate toward declining industries whose competitiveness in international markets can only be sustained by offering wages and working conditions that are unattractive to indigenous workers. Older workers in these industries (both immigrant and nonimmigrant) are retiring, while younger indigenous workers enter better paid jobs in expanding sectors. The effect of discrimination is to block the mobility opportunities for ethnic minorities and to delay the effective integration of recently arrived immigrants from nontraditional source countries. Temporary workers include males who are employed in agriculture, construction and manufacturing and women who are mainly engaged in domestic service.

A "segmented structural change" model of immigrant adaptation to the labor market describes the experience of Canada in recent decades. It remains for further comparative research to be undertaken to determine whether the experience of other countries can be explained in similar terms.

\author{
REFERENCES \\ Beaujot, R. and P. Rappak \\ 1989 "The Role of Immigration in Changing Socio-economic Structures," The Review of \\ Demography and Its Implications for Economic and Social Policy, 5:57-62. \\ Beaujot, R., K. G. Basavarajappa and R. B. P. Verma \\ 1988 The Income of Immigrants in Canada. Ottawa: Statistics Canada. \\ Borjas, G. J. \\ 1988 International Differences in the Labor Market Performance of Immigrants. Kalamazoo, MI: \\ W. E. Upjohn Institute for Employment Research. \\ Cumming, P., E. Lee and D. G. Oreopolis \\ 1989 Access! Task Force on Access to Professions and Trades in Ontario. Toronto: Ontario Ministry \\ of Citizenship. \\ Manpower and Immigration \\ 1974 Three Years in Canada. Ottawa: Supply and Services. \\ Marr, W. L. \\ 1986 "Are the Canadian Foreign-born Under-Represented in Canada's Occupational Struc- \\ ture?" International Migration, 24(4):769-775.
}


McDade, $\mathbf{K}$.

1988 Barriers to the Recognition of the Credentials of Immigrants in Canada. Ottawa: Institute for Research in Public Policy.

Richmond, A. H.

1989 Caribbean Immigrants: A Demo-economic Analysis. Ottawa: Statistics Canada.

1967 Postwar Immigrants in Canada. Toronto: University of Toronto Press.

Richmond, A. H. and W. E. Kalbach

1980 Adjustment of Immigrants and Their Descendants. Ottawa: Statistics Canada.

Richmond, A. H. and J. Zubrzycki

1984 Immigrants in Canada and Australia: Economic Adaptation. Vol. 2. Toronto: York University, Institute for Behavioral Research.

Seward, $S$.

1990 Challenges of Labour Adjustment: The Case of Immigrant Women in the Clothing Industry. Ottawa: Institute for Research on Public Policy.

Seward, S. and M. Tremblay

1990 "Immigration and the Changing Labour Market." Paper presented at Canadian Population Society, Victoria, B.C.

Seward, S. and M. Tremblay

1989 Immigrants in the Canadian Labour Force: Their Role in Structural Change. Ottawa: Institute for Research in Public Policy.

Statistics Canada

19891986 Census of Canada: Profile of Immigrants. Cat. 93-155. Ottawa: Supply and Services.

Verma, R. B. P. and K. G. Basavarajappa

1989 "Employment Income of Immigrants in Metropolitan Areas of Canada, 1980," International Migration, 27(3):441- 466. 